\title{
The role of mosaicity of the post-agriculture area of the Kampinos National Park in determining the diversity of species of spider wasps (Hymenoptera: Pompilidae)
}

\author{
Katarzyna SZCZEPKO ${ }^{1}$, ANDRZeJ KRUK ${ }^{2 *}$ and Maciej BARTOS ${ }^{1}$ \\ ${ }^{1}$ Department of Didactics in Biology and Biodiversity Studies, Faculty of Biology and Environmental Protection, \\ University of Łódź, 1/3 Banacha Str., 90-237 Łódź, Poland; e-mails: kawa@biol.uni.lodz.pl, bartos@biol.uni.lodz.pl \\ ${ }^{2}$ Department of Ecology and Vertebrate Zoology, Faculty of Biology and Environmental Protection, University of Łódź, \\ 12/16 Banacha Str., 90-237 Łódź, Poland; e-mail: a.kruk@biol.uni.lodz.pl
}

Key words. Hymenoptera, predatory Aculeata, Pompilidae, UNESCO World Biosphere Reserve, habitat heterogeneity, nesting behaviour, bioindication, self-organizing map, Kohonen artificial neural network

\begin{abstract}
From 2000 to 2006 a total of 52 CPUE samples of spider wasps (Hymenoptera: Pompilidae) were collected in the mosaic landscape of the Kampinos National Park (Poland), which is a UNESCO Biosphere Reserve. The hypothesis tested was that both pompilid species richness and abundance is positively associated with spatial heterogeneity. The patterns in spider wasp assemblages were identified using a Kohonen artificial neural network (i.e., self-organizing map). The highest numbers and greatest species richness of pompilids were recorded at sites in open habitats, especially those located on dry soils that are the preferred nesting sites of ground nesting (endogeic) spider wasps. However, pompilid distribution depended not only on the character of a sampling site, but also its location in a mosaic of habitats. The highest values of pompilid abundance and species richness were also recorded at sites surrounded by several different habitats. Both parameters were lower at sites in more homogenous areas, where there were fewer habitats within the flight ranges of spider wasps. A group of three "cultural species" (Agenioideus cinctellus, A. sericeus and Auplopus carbonarius) was identified that is significantly associated with wooden buildings. The results of this study are thus consistent with the concept that habitat heterogeneity enhances faunal diversity, as each type of habitat, including anthropogenic ones, potentially contributes to a wider range of available resources.
\end{abstract}

\section{INTRODUCTION}

Members of different genera or even subfamilies of Pompilidae look very similar, which is why their identification requires both experience and patience (Wiśniowski, 2009). Traditionally the study of this group has been regarded as difficult (Day, 1988). Probably this is why there are only a few ecological papers on pompilids. The latter are studied either as a part of (1) assemblages of predatory Aculeata occurring in certain habitats including raised bogs (Shlyakhtenok, 2007), pine forests (Shlyakhtenok \& Agunovich, 2001), linden-oak-hornbeam and thermophilous oak forests and moist meadows (Skibińska, 1989a, b), or (2) a guild of cavity-nesting Aculeata (Tscharntke et al., 1998; Buschini \& Woiski, 2008). Moreover, except for the papers of Wiśniowski (2005) and Wiśniowski \& Werstak (2009), there are none on the relationship between the distribution of pompilids and their habitat preferences.

Each species of insect requires a particular set of resources (Speight et al., 2008). The resources used by spider hunting wasps are complex and diverse. They need appropriate nesting sites, nectar or aphid honeydew as a source of energy for adults and a spider-host for larval development (Day, 1988; O’Neill, 2001; Wiśniowski, 2009). Nesting behaviour and prey choice varies within the family (Evans \& West-Eberhard, 1970; Day, 1988; O’Neill, 2001; Wiśniowski, 2009). Pompilids hunt for spiders of many families, choosing spiders of an ecological group rather than a particular species (Finch, 1997; Wiśniowski, 2009) and visit plants of many families (Wiśniowski, 2009). Nesting strategies of the different species vary with respect to the part of a habitat in which they build their nest, the type of substrate they use and the materials required for nest construction (Evans \& West-Eberhard, 1970; Day, 1988; O’Neill, 2001; Wiśniowski, 2009). This variability in the requirements of the different species accounts for their different responses to particular habitats (Day, 1988; Wiśniowski, 2009).

Pompilid species, therefore, are found in environments where they encounter appropriate living conditions. Thus, their species richness and abundance should be positively associated with the diversity of habitats (landscape mosaicity) in an area, which is the hypothesis tested in this paper. The Kampinos National Park (Poland) was chosen for this study because the mosaic landscape of this UNESCO Biosphere Reserve should presumably enhance survival of species and promote diversity (Weibull et al., 2000; Steffan-Dewenter, 2002; Bennett et al., 2006) of this rarely studied group of Aculeata.

\footnotetext{
* Corresponding author.
} 


\section{MATERIAL AND METHODS}

\section{Study area}

The Kampinos National Park (KNP) is located in Central Poland $\left(52^{\circ} 25^{\prime}-52^{\circ} 15^{\prime} 30^{\prime \prime} \mathrm{N} ; 20^{\circ} 17^{\prime}-20^{\circ} 53^{\prime} \mathrm{E}\right)$, on Mazovian Lowland, close to Warsaw, which is on its eastern border. The park was created in 1959 and in 2000 was declared a UNESCO World Biosphere Reserve "Puszcza Kampinoska". KNP covers 38,544 ha, of which 4,303 ha are designated as reserves (areas of strict protection) around which there is a buffer zone of 37,756 ha (Andrzejewski, 2003). The mean annual temperature is $7.7^{\circ} \mathrm{C}$ and annual precipitation $547 \mathrm{~mm}$. The Park has a beltlike structure consisting of belts of sand dunes separated by wide belts of swampy depressions, which run parallel to the Vistula River, from east to west. The following belts are distinguished: two (northern and southern) belts of dunes and two belts of inter-dune swampy depressions (the Lasica Canal depression and bipartite southern belt of the Olszowiecki and Zaborów Canals (Fig. 1). The KNP dunes are considered the best preserved complex of inland dunes in Europe. Forest communities dominate the vegetation in the KNP covering $73 \%$ of the park area. The forest vegetation consists mostly of pine wood phytocenoses. These communities are typical of sites with sandy soils in the two dune belts. In the swampy belts with hydrogenic soils there is meadow vegetation, reed beds, shrubs (mainly willow) and bog forests (alder-ash and alder forests) (Andrzejewski, 2003).

Since the late 1970s this area has been gradually depopulated and the land incorporated into the KNP and forested or left to natural succession. Now the KNP is characterized by a very diverse landscape. Natural (forests) and semi-natural (grasslands, dunes, meadows, fallow fields) habitats are interspersed with human settlements, abandoned or still inhabited (buildings and farms) (Andrzejewski, 2003).

This study was carried out in the western part of the KNP, in Bieliny, Bromierzyk, Granica, Famułki Brochowskie, Lasocin, Miszory, Olszowiec, Pieklice, Pindal and Łazy, which are in the buffer zone (Fig. 1). Sampling was carried out in the northern swampy belt (constituting the valley of the Lasica Canal) and in the southern dune belt, at a total of 35 sites, of which: (1) 14 were located in fallows that were small fields $\left(3000-4000 \mathrm{~m}^{2}\right)$ abandoned at different times, with naturally developed vegetation (the last crops were cereals or potatoes); 1-2 year old fallows were regarded as at a pioneer successional stage; (2) two in meadows: an un-mowed wet meadow of the Calthion alliance and a mowed (once a year in June) fresh meadow of the Arrhenatherion alliance; (3) two in psammophilous grasslands of the Koelerio glaucae-Corynephoretea canescentis class: a small area $\left(150 \mathrm{~m}^{2}\right)$ of grassland surrounded by woodland consisting largely of oak Quercus robur, pine Pinus sylvestris and black locust Robinia pseudoacacia, and the other $\left(450 \mathrm{~m}^{2}\right)$ bordered by Cladonia heath, Pinus sylvestris woodland, scrub of Betula pendula and Robinia pseudacacia and mixed forest; (4) one on a small sand dune $\left(150 \mathrm{~m}^{2}\right)$, about $1.3 \mathrm{~m}$ high, surrounded by mixed forest; (5) one in a degenerated bog alder forest Ribo nigri-Alnetum; (6) one in fresh coniferous forest Pino-Quercetum; (7) one in a ruderal habitat of the Artemisietea class on an abandoned farm, with the remnants of walls and foundations; (8) one on old fruit trees (pear and apple-tree) in a ruderal habitat of the Artemisietea class; and, (9) 12 on southern walls of 80 to 150 year old wooden buildings (Table 1,2).

\section{Methods}

During 2000-2006, between early April and the beginning of October, a total of 52 samples of spider wasps were collected. Each sample was marked with a code consisting of (1) two digits indicating the site and (2) two letters the habitat sampled (FA - fallow, ME - meadow, PG - psammophilous grassland, SD - sand dune, FR - forest, FT - fruit trees, AF - abandoned farm, and WB - wooden building); codes for samples from fallows additionally contain two digits indicating the age (in years) of the fallow; each code ends with 2 digits in subscript indicating the year sampled (Table 1). For example: the sample 24FA06 05 was collected in 2005 at site No 24 located in fallow land abandoned 6 years previously. Because open habitats are preferred by most pompilid species, the samples were collected mainly in open areas. The numbers of samples from the latter reflect to a certain extent the diversity of the landscape outside dense forests, i.e. the number of samples collected differed between habitats in order to avoid habitat under- and overrepresentation in the dataset. Samples from dense forest were collected just in order to provide a point of reference.

More than one sample was collected in successive years at some sites located in fallows (28 samples), meadows (4 samples) and fresh coniferous forest (2 samples) (Table 1). The repetitions could either be deleted in order to base the study on a single sample from each site, or included in the analyses. In an attempt to determine whether other effects are revealed when a richer dataset is used, the latter option was adopted.

The catches of pompilid wasps were standardized by expressing them in terms of catch per unit effort (CPUE) using water pan-traps. Each trap was a plastic bowl, $20 \mathrm{~cm}$ in diameter, filled two-third full with a mixture of water (95\%), glycol (5\%) for preservation and a detergent to break the surface tension. Three traps (two yellow and one white) were placed at each site: (1) on the ground; (2) on poles at the same height as the mean height of the surrounding vegetation; (3) hung on trees; or, (4) placed on the walls of buildings. Each trap was emptied 19 times at ten day intervals during the study. The 19 catches from 3 traps at a site in a given year were treated as one sample. During this study 156 pan traps were used.

Water pan traps, especially yellow and white ones, are effective tools for collecting flower-visiting insects, including pompilids (Duelli et al., 1998; Wiśniowski, 2009). This low cost method is not only reliable, but also simple to use and inconspicuous. The latter feature was especially important, because Malaise traps were often stolen or destroyed. Moreover, the pan traps could be used in all the habitats studied unlike Malaise traps or sweeping (both not appropriate for collecting samples on buildings) (Westphal et al., 2008). The effectiveness of pan traps is not dependent on the size, conspicuousness and diurnal activity of insects, weather or researcher's experience, all of which considerably influence results based on sweeping or transect walk (Westphal et al., 2008; Wiśniowski, 2009).

Captured insects were preserved in $75 \%$ ethanol. In the laboratory, specimens were mounted and labelled. Identification was based on: Oehlke \& Wolf (1987); Smissen (1994, 1996a, b, 1998, 2003); Schmid-Egger \& Smissen (1995) and Wiśniowski (2009). The nomenclature of the insects follows Fauna Europaea (2010). The reference collection for this study is deposited at the Department of Didactics in Biology and Biodiversity Studies, University of Łódź.

Information on the preferred habitats and nesting behaviour of the species was based on the papers by Day (1988) and Wiśniowski (2009). Each species was classified according to its habitat preferences in one of four groups: (1) eurytopic, associated with open areas; (2) thermophilous, associated with open areas; (3) cleptoparasites, thermophilous, associated with open areas; and, (4) associated with woodland areas and forest edges. To characterize nesting habits, the species were divided into the following seven guilds (Evans \& West-Eberhard, 1970): (i) no nest constructed, prey left in situ; (ii) no nest constructed, clep- 

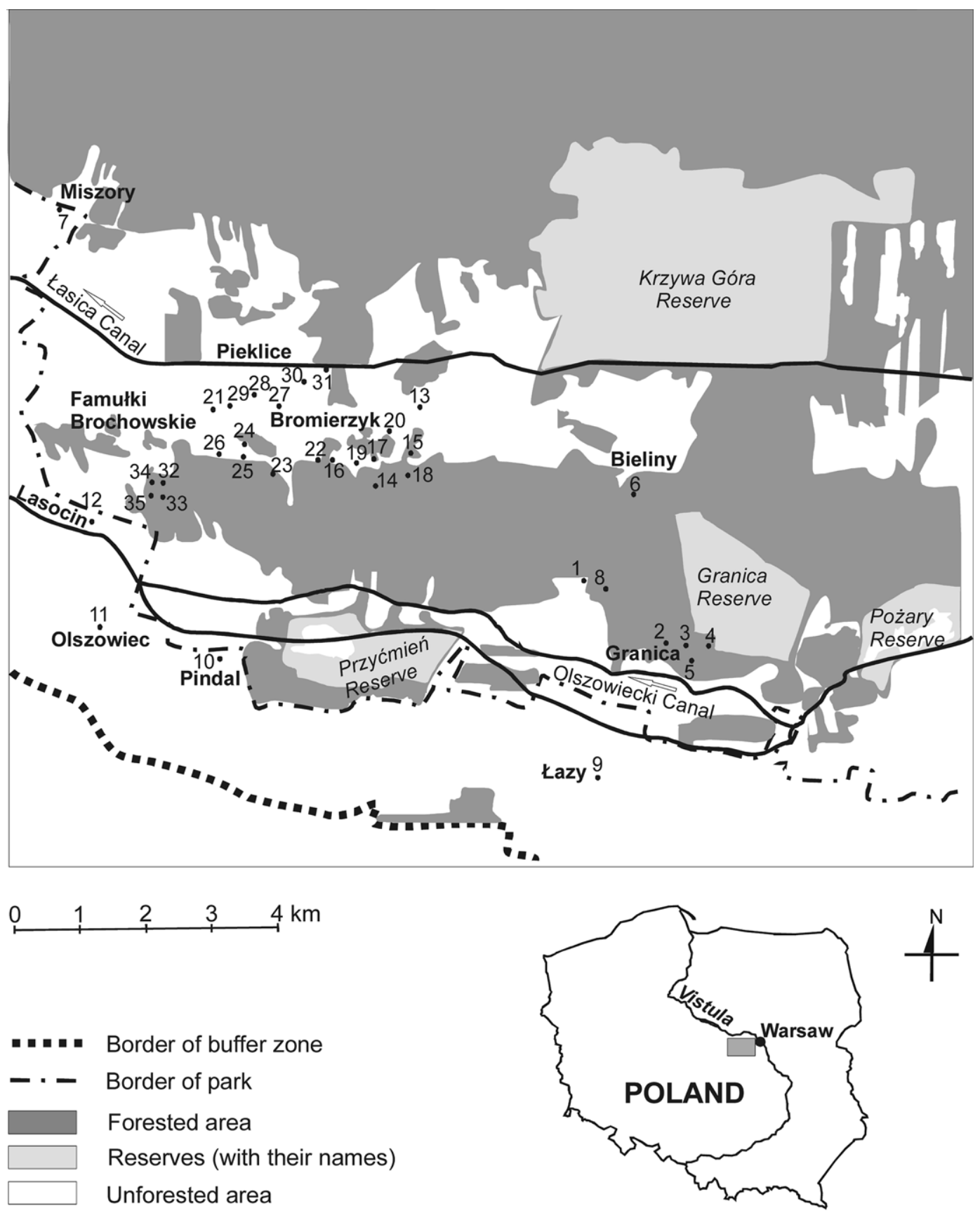

Fig. 1. Map of the study area with sites sampled marked with black circles. Names of localities are in bold font.

toparasites; (iii) nest dug in the ground; (iv) nest in pre-existing cavities in the ground; (v) nest in pre-existing cavities in or above the ground; (vi) nest in pre-existing cavities above the ground; and, (vii) free standing nest above the ground.

The patterns in the abundance of spider wasps were determined using a Kohonen artificial neural network (ANN). Kohonen ANNs are also referred to as self-organizing maps (SOMs). Like all ANNs, they easily deal with non-linearly related variables that are skewly distributed, which is especially useful in analyses of organism counts. The latter are seldom normally distributed (because of many zeroes) and usually it is not possible to normalise them with any transformation (Quinn $\&$ Keough, 2002). The unequal number of samples collected from the habitats and/or sites studied is also not a problem in sample ordination performed with Kohonen ANNs.
ANNs are simple structural and functional models of a human brain. They consist of processing units called neurons or nodes. Kohonen ANNs are built of two (input and output) layers of neurons. The number of input neurons is equal to the number of variables (in this study the abundances of 42 taxa). The output neurons are arranged on a two-dimensional lattice (in this study $4 \times 4$, selected arbitrarily from among other tested options) (Fig. 2 ). The dataset (42 taxa $\times 52$ samples, $\log$ transformed and normalised 0-1) was presented to the input neurons. Each input neuron transmitted information to all the output neurons during the training process. On this basis a model of a spider wasp sample was created in each output neuron. Similarity of sample models is related to the SOM topology, i.e., models in distant neurons differ and those in neighbouring neurons are similar. A given spider wasp sample was finally assigned to the most similar model and the respective output neuron. As a conse- 
TABLE 1. Details of the pompilid samples collected.

\begin{tabular}{|c|c|c|c|c|c|c|}
\hline Sample code & Site number & Habitat sampled & Fallow age & $\begin{array}{c}\text { Year } \\
\text { sampled }\end{array}$ & $\begin{array}{l}\text { Number of other } \\
\text { adjacent habitats }\end{array}$ & $\begin{array}{l}\text { Number } \\
\text { of species }\end{array}$ \\
\hline $01 \mathrm{WB}_{00}$ & 1 & wooden building & $x$ & 2000 & 2 & 4 \\
\hline $02 \mathrm{WB}_{00}$ & 2 & wooden building & $x$ & 2000 & 1 & 3 \\
\hline $03 \mathrm{WB}_{00}$ & 3 & wooden building & $\times$ & 2000 & 1 & 3 \\
\hline $04 \mathrm{WB}_{00}$ & 4 & wooden building & $x$ & 2000 & 2 & 8 \\
\hline $05 \mathrm{WB}_{00}$ & 5 & wooden building & $x$ & 2000 & 1 & 4 \\
\hline $06 \mathrm{WB}_{00}$ & 6 & wooden building & $x$ & 2000 & 2 & 5 \\
\hline $07 \mathrm{WB}_{00}$ & 7 & wooden building & $x$ & 2000 & 1 & 1 \\
\hline $08 \mathrm{WB}_{01}$ & 8 & wooden building & $x$ & 2001 & 2 & 6 \\
\hline $09 \mathrm{WB}_{01}$ & 9 & wooden building & $x$ & 2001 & 1 & 1 \\
\hline $10 \mathrm{WB}_{01}$ & 10 & wooden building & $x$ & 2001 & 1 & 3 \\
\hline $11 \mathrm{WB}_{01}$ & 11 & wooden building & $x$ & 2001 & 2 & 4 \\
\hline $12 \mathrm{WB}_{01}$ & 12 & wooden building & $x$ & 2001 & 1 & 2 \\
\hline $13 \mathrm{AF}_{02}$ & 13 & abandoned farm & $x$ & 2002 & 0 & 6 \\
\hline $14 \mathrm{FR}_{02}$ & 14 & coniferous forest & $x$ & 2002 & 0 & 5 \\
\hline $14 \mathrm{FR}_{03}$ & 14 & coniferous forest & $x$ & 2003 & 0 & 6 \\
\hline $15 \mathrm{FR}_{02}$ & 15 & alder forest & $x$ & 2002 & 0 & 2 \\
\hline $16 \mathrm{FT}_{02}$ & 16 & fruit trees & $x$ & 2002 & 4 & 11 \\
\hline $17 \mathrm{SD}_{02}$ & 17 & sand dune & $x$ & 2002 & 1 & 6 \\
\hline $18 \mathrm{PG}_{02}$ & 18 & psammophilous grassland & $x$ & 2002 & 1 & 8 \\
\hline $19 \mathrm{PG}_{02}$ & 19 & psammophilous grassland & $x$ & 2002 & 3 & 9 \\
\hline $20 \mathrm{ME}_{01}$ & 20 & meadow & $x$ & 2001 & 2 & 1 \\
\hline $20 \mathrm{ME}_{02}$ & 20 & meadow & $x$ & 2002 & 2 & 7 \\
\hline $21 \mathrm{ME}_{03}$ & 21 & meadow & $x$ & 2003 & 2 & 9 \\
\hline $21 \mathrm{ME}_{04}$ & 21 & meadow & $x$ & 2004 & 2 & 9 \\
\hline $22 \mathrm{FA} 03_{03}$ & 22 & fallow & 3 & 2003 & 4 & 19 \\
\hline $22 \mathrm{FA} 04_{04}$ & 22 & fallow & 4 & 2004 & 4 & 18 \\
\hline $22 \mathrm{FA} 05_{05}$ & 22 & fallow & 5 & 2005 & 4 & 10 \\
\hline $23 \mathrm{FA} 10_{03}$ & 23 & fallow & 10 & 2003 & 3 & 10 \\
\hline $23 \mathrm{FA} 11_{04}$ & 23 & fallow & 11 & 2004 & 3 & 13 \\
\hline $24 \mathrm{FA} 04_{03}$ & 24 & fallow & 4 & 2003 & 3 & 14 \\
\hline $24 \mathrm{FA} 05_{04}$ & 24 & fallow & 5 & 2004 & 3 & 15 \\
\hline $24 \mathrm{FA} 06_{05}$ & 24 & fallow & 6 & 2005 & 3 & 8 \\
\hline $25 \mathrm{FA} 03_{03}$ & 25 & fallow & 3 & 2003 & 3 & 15 \\
\hline $25 \mathrm{FA} 04_{04}$ & 25 & fallow & 4 & 2004 & 3 & 14 \\
\hline $26 \mathrm{FA} 07_{03}$ & 26 & fallow & 7 & 2003 & 4 & 15 \\
\hline $26 \mathrm{FA} 08_{04}$ & 26 & fallow & 8 & 2004 & 4 & 16 \\
\hline $27 \mathrm{FA} 01_{03}$ & 27 & fallow & 1 & 2003 & 0 & 2 \\
\hline $27 \mathrm{FA} 02_{04}$ & 27 & fallow & 2 & 2004 & 0 & 2 \\
\hline $28 \mathrm{FA} 01_{04}$ & 28 & fallow & 1 & 2004 & 0 & 9 \\
\hline $28 \mathrm{FA} 02_{05}$ & 28 & fallow & 2 & 2005 & 0 & 8 \\
\hline $28 \mathrm{FA} 03_{06}$ & 28 & fallow & 3 & 2006 & 1 & 13 \\
\hline $29 \mathrm{FA} 02_{04}$ & 29 & fallow & 2 & 2004 & 1 & 2 \\
\hline $30 \mathrm{FA} 01_{04}$ & 30 & fallow & 1 & 2004 & 0 & 8 \\
\hline $30 \mathrm{FA} 02_{05}$ & 30 & fallow & 2 & 2005 & 0 & 9 \\
\hline $31 \mathrm{FA} 01_{04}$ & 31 & fallow & 1 & 2004 & 0 & 10 \\
\hline $32 \mathrm{FA} 10_{05}$ & 32 & fallow & 10 & 2005 & 3 & 9 \\
\hline $33 \mathrm{FA} 15_{05}$ & 33 & fallow & 15 & 2005 & 3 & 8 \\
\hline $33 \mathrm{FA} 16_{06}$ & 33 & fallow & 16 & 2006 & 3 & 11 \\
\hline $34 \mathrm{FA} 05_{05}$ & 34 & fallow & 5 & 2005 & 4 & 8 \\
\hline $34 \mathrm{FA} 06_{06}$ & 34 & fallow & 6 & 2006 & 4 & 14 \\
\hline $35 \mathrm{FA} 20_{05}$ & 35 & fallow & 20 & 2005 & 3 & 6 \\
\hline $35 \mathrm{FA} 21_{06}$ & 35 & fallow & 21 & 2006 & 3 & 11 \\
\hline
\end{tabular}

quence, samples in distant neurons are dissimilar while samples in nearby neurons are similar. The latter may not be true if the neighbouring neurons are in different clusters. The clusters of neurons and respective sample models were identified using a hierarchical cluster analysis (Ward linkage, Euclidean distance). More details on Kohonen ANNs are available in many papers on the ecology of invertebrates (Chon et al., 2001; Park et al., 2003; Lek et al., 2005; Penczak et al., 2006; Song et al., 2006; Lek-Ang at al., 2007; Céréghino et al., 2008; Ruggiero et al., 2008; Tszydel et al., 2009; Bańbura et al., 2010). It is worth mentioning that there are a few studies employing SOMs on terrestrial arthropods (Park \& Chung, 2006), including hymenop- 

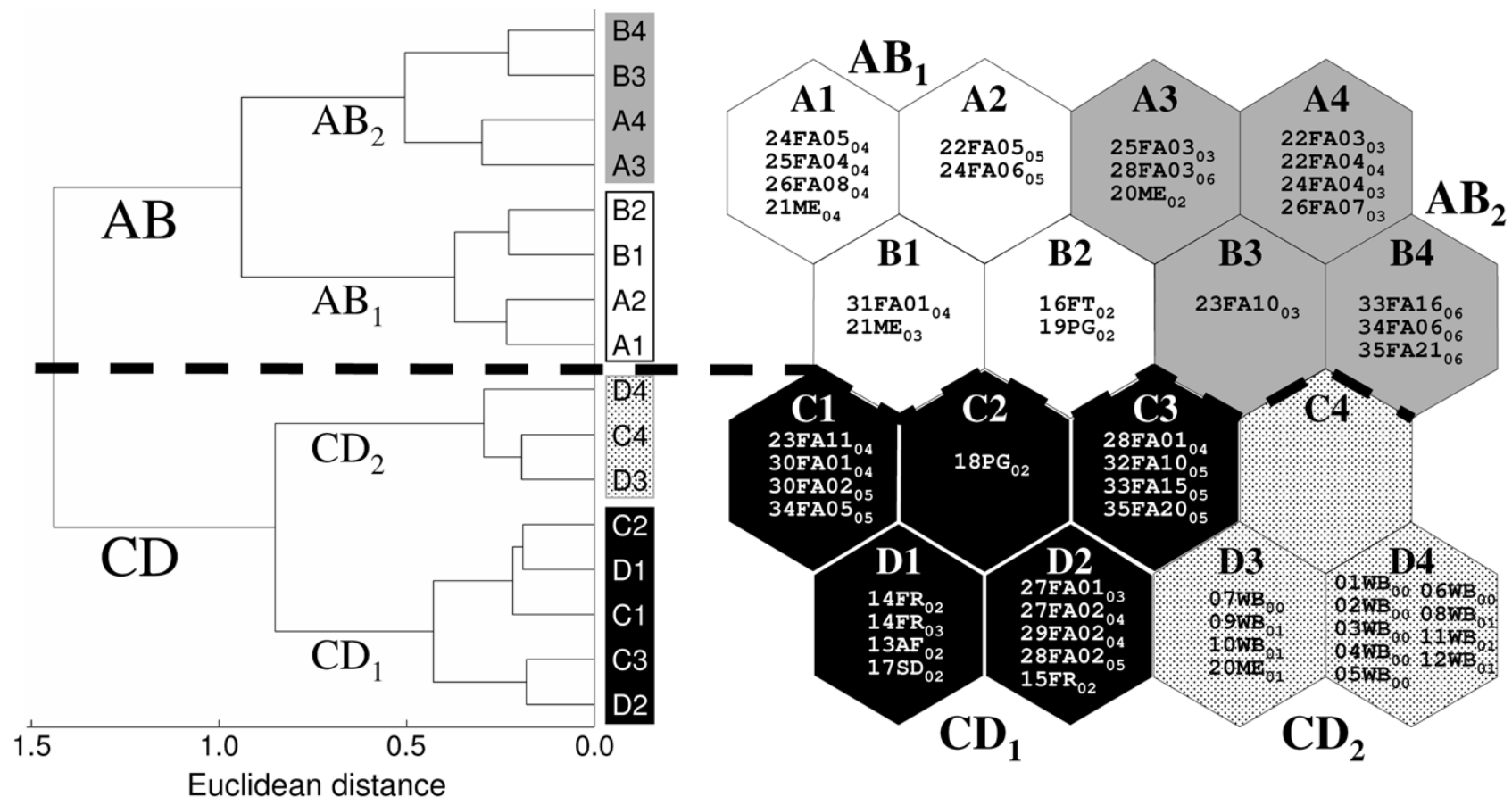

Fig. 2. The 52 samples of spider wasps assigned to $16 \mathrm{SOM}$ output neurons arranged in a two dimensional grid $(4 \times 4)$. Clusters ( $\mathrm{AB}$ and $\mathrm{CD}$; separated by a dashed line) and sub-clusters $\left(\mathrm{AB}_{1}, \mathrm{AB}_{2}, \mathrm{CD}_{1}, \mathrm{CD}_{2}\right.$; are shaded) of neurons and respective sample models were identified using a hierarchical cluster analysis. The code for each sample of spider wasps consists of the site number and two letters for the habitat (AF - abandoned farm, FA - fallow, FT - fruit trees, FR - forest, ME - meadow, PG - psammophilous grassland, SD - sand dune, WB - wooden building); codes for samples from fallows additionally include two digits for the age of the fallow (in years); each code ends with 2 digits in subscript indicating the year the sample was collected.

terans like ants (Groc et al., 2007; Delabie et al., 2009) or social wasps (Corbara et al., 2009). To our knowledge, there are no studies of the patterns in pompilid assemblages using SOMs.

The software used for simulation of the SOM (SOM Toolbox for Matlab, by LADYBIO, Université Paul Sabatier, Toulouse) allows for the visualization of each species relative abundance in models of a spider wasp samples in the output neurons in the form of a gradient of greyness. This visualization may be very helpful in formulating ecological conclusions as species with the same pattern of greyness in the SOM usually have similar habitat preferences. Additionally, the species association with each SOM sub-cluster of neurons (and respective environmental conditions) can be expressed in numeric form using the indicator value (IndVal) of Dufrêne \& Legendre (1997). The IndVal for a species in a sub-cluster of neurons was calculated as a product of (1) species frequency in the sub-cluster, (2) average relative species abundance, i.e. average species abundance in the sub-cluster over the sum of average abundances of the species in all sub-clusters, and (3) a constant 100 in order to produce percentages. IndVal has a maximum $(100 \%)$ when all spider wasp samples with a given species are in a single subcluster of neurons, and when the species was recorded in all samples assigned to that sub-cluster (Dufrêne \& Legendre, 1997). The significance level of the maximum observed IndVal for each species was calculated using a Monte Carlo test. Hence, the IndVals and SOM species planes express (numerically and in the form of a gradient greyness, respectively) the importance of each SOM region to a species and thus complement each other. Both allow an identification of the sub-cluster of neurons in which a given species is most abundant and frequent and thus the abiotic conditions it prefers. Nevertheless, species planes produced for sporadically recorded species may be misleading. This is why they were not drawn for species with maximum
IndVal $\leq 15 \%$ (arbitrary criterion). Thus, species planes are not presented for the following 14 species: Arachnospila rufa (Haupt, 1927), A. spissa (Schiödte, 1837), Anoplius caviventris (Aurivillius, 1907), Evagetes proximus (Dahlbom, 1845), E. subglaber (Haupt, 1941), Pompilius cinereus (Fabricius, 1775), Priocnemis agilis (Schuckard, 1837), P. fennica Haupt, 1927, P. gracilis Haupt, 1927, P. hankoi Móczar, 1944, P. minuta (Vander Linden, 1827), P. parvula Dahlbom, 1845, P. pusilla (Schiödte, 1837) and P. vulgaris (Dufour, 1841) (Table 3).

The data on the type of soil at particular sites come from Konecka-Betley (2003) and Piórkowski et al. (in prep.) and were analyzed using the ArcGIS 9.3.1. computer program. The soil at each open site was classified as either: (1) nonhydrogenic, autogenic (dry) soil (podzolized soil, podzol) or (2) hydrogenic (humid) soil (moorsh, muckous soil). Habitat heterogeneity in the vicinity of each site was described as the number of habitats adjoining the habitat studied (Table 1). The significance of the differences between the SOM sub-clusters in this variable, as well as in the numbers of specimens of spider wasp and of spider wasp species richness in samples was assessed using a Kruskal-Wallis test (Zar, 1984).

\section{RESULTS}

A total of 2318 spider wasps (Pompilidae) belonging to 42 species were captured at the sites studied (Table 3 ). The highest abundances of pompilids were recorded in meadows (on average 60.5 specimens per sample), fallows (52.5, ranging from 34.9 in pioneer to 59.6 in old fallows), on an abandoned farm (39 specimens), wooden buildings (34.6 specimens), and in forests, on fruit trees and in psammophilous grasslands $(25,23$ and 21.5 specimens, respectively). The minimum value was recorded at 
TABLE 2. Number of spider wasp samples assigned to SOM subclusters in relation to the type of habitats and humidity of soil in open areas. Abbreviations of habitat names: AF - abandoned farm, FA - fallow, FT - fruit trees, FR - forest, ME - meadow, PG psammophilous grassland, SD - sand dune, WB - wooden building.

\begin{tabular}{|c|c|c|c|c|c|c|c|c|c|c|}
\hline \multirow{3}{*}{ Subcluster } & \multicolumn{7}{|c|}{ Open habitats } & \multirow{3}{*}{ FR } & \multirow{3}{*}{ WB } & \multirow{3}{*}{ Total } \\
\hline & \multicolumn{4}{|c|}{ On dry soil } & \multicolumn{3}{|c|}{ On humid soil } & & & \\
\hline & FA & $\mathrm{PG}$ & $\mathrm{SD}$ & FT & FA & $\mathrm{ME}$ & $\mathrm{AF}$ & & & \\
\hline $\mathrm{AB}_{1}$ & 5 & 1 & & 1 & 1 & 2 & & & & 10 \\
\hline $\mathrm{AB}_{2}$ & 9 & & & & 1 & 1 & & & & 11 \\
\hline $\mathrm{CD}_{1}$ & 5 & 1 & 1 & & 7 & & 1 & 3 & & 18 \\
\hline $\mathrm{CD}_{2}$ & & & & & & 1 & & & 12 & 13 \\
\hline Total & 19 & 2 & 1 & 1 & 9 & 4 & 1 & 3 & 12 & 52 \\
\hline
\end{tabular}

a sand dune site (11 specimens). The dominant species were Priocnemis perturbator (Harris, 1780) (23.5\%), Agenioideus cinctellus (Spinola, 1808) (12.1\%) and Anoplius viaticus (Linnaeus, 1758) (10.8\%).

The hierarchical cluster analysis identified the following two clusters of neurons in the output layer of the SOM: AB (neurons A1-B4) and CD (neurons C1-D4) (Fig. 2). In each of these clusters there were two subclusters: $\mathrm{AB}_{1}$ (neurons $\mathrm{A} 1, \mathrm{~A} 2, \mathrm{~B} 1, \mathrm{~B} 2$ ) and $\mathrm{AB}_{2}$ (neurons $\mathrm{A} 3, \mathrm{~A} 4, \mathrm{~B} 3, \mathrm{~B} 4$ ) in cluster $\mathrm{AB}$, and $\mathrm{CD}_{1}$ (neurons $\mathrm{C} 1-\mathrm{C} 3$, $\mathrm{D} 1, \mathrm{D} 2$ ) and $\mathrm{CD}_{2}$ (neurons $\left.\mathrm{C} 4, \mathrm{D} 3, \mathrm{D} 4\right)$ in cluster $\mathrm{CD}$. The number of spider wasp samples assigned to the neurons in the $\mathrm{AB}$ and $\mathrm{CD}$ clusters was 21 and 31, respectively (Fig. 2 and Table 2).

Clear differences between the clusters in the spatial origin of the samples were recorded, as cluster AB contained only samples from open areas, mainly those from (1) fallows and meadows (90\%), and, (2) habitats located on dry soil (76\%) (Table 2). Cluster CD grouped all samples from wooden buildings, forests and $43 \%$ of the samples from fallows (Table 2). Within cluster AB, the samples in sub-cluster $\mathrm{AB}_{1}$ had a mixed composition, but mainly included samples from fallows and meadows, while in sub-cluster $\mathrm{AB}_{2}$ almost all the samples were from fallows on dry soil (Table 2). Within cluster $\mathrm{CD}$, subcluster $\mathrm{CD}_{1}$ contained samples from various sites, but mainly from (1) fallows including almost all samples from 1-2 year old fallows, i.e. in a pioneer successional stage, and the majority of samples (7 out of 9) from fallows on humid soils, and (2) forests (all samples from this habitat). Sub-cluster $\mathrm{CD}_{2}$ was the only one that did not include samples from fallows; it was comprised only of samples collected on wooden buildings (with one exception) (Fig. 2 and Table 2); its homogeneity was also manifest in the fact that all the 13 samples were assigned to only two neurons (D3, D4) (Fig. 2).

Both clusters and sub-clusters significantly $(p<0.001)$ differed in the environmental heterogeneity in the vicinity of the sites sampled (Fig. 3). Samples assigned to cluster $\mathrm{AB}$ were collected at sites surrounded by more types of habitats than those in cluster CD (Fig. 3).

The abundance of spider wasps in the samples assigned to sub-clusters $A_{1}$ and $A B_{2}$ was significantly greater than in sub-clusters $C_{1}$ and $C_{2}$ (Fig. 3). Also the species richness in sub-clusters $A B_{1}$ and $A B_{2}$ was significantly greater than in $\mathrm{CD}_{1}$ and $\mathrm{CD}_{2}$, and additionally in $\mathrm{CD}_{1}$ than in $\mathrm{CD}_{2}$ (Fig. 3). Similarly, a greater total species richness
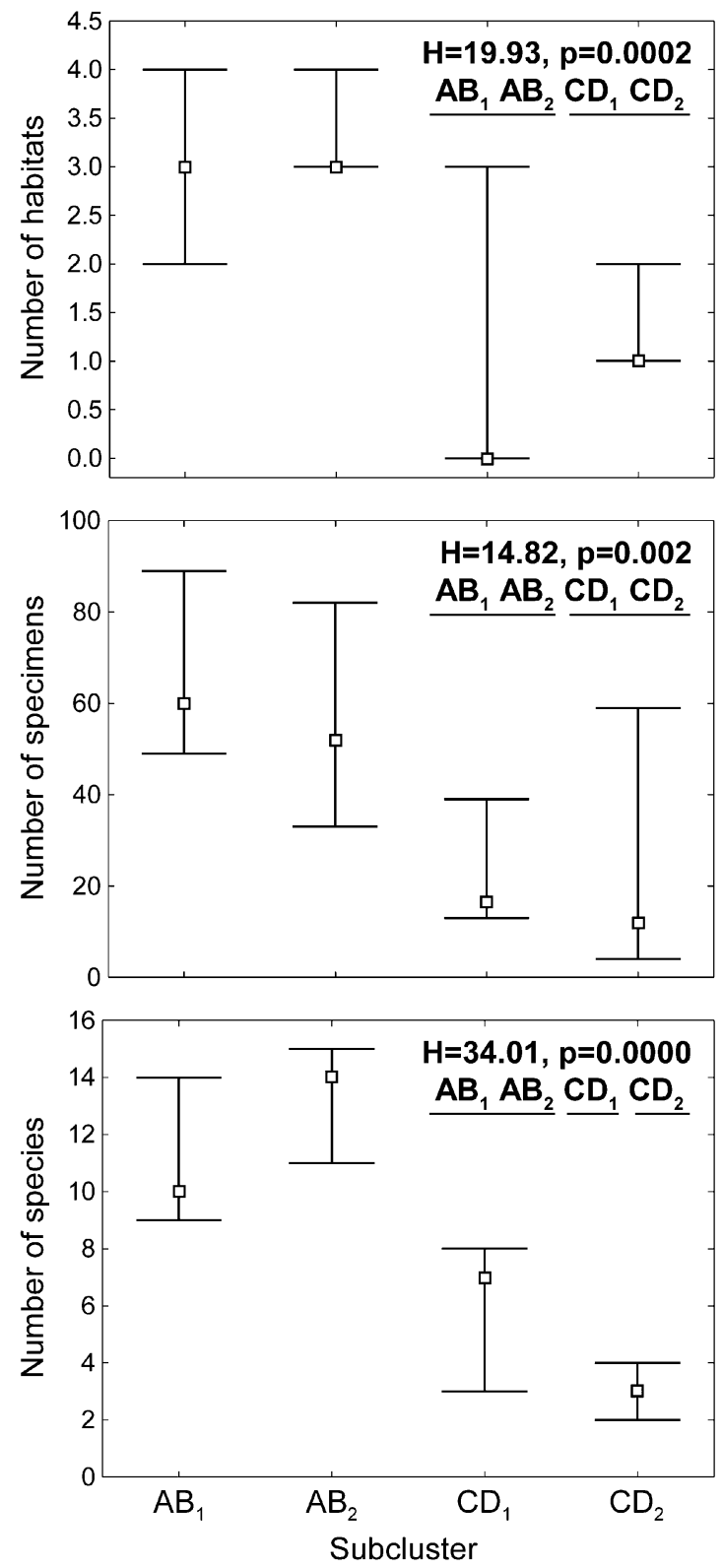

Fig. 3. Number of other habitats adjacent to a sampled habitat, number of pompilid wasps and species richness of a sample. Point indicates the median, whiskers the inter-quartile range. $\mathrm{H}$ is the statistics of the Kruskal-Wallis test $\left(\mathrm{df}=3, \mathrm{~N}_{\mathrm{AB} 1}\right.$ $=10, \mathrm{~N}_{\mathrm{AB} 2}=11, \mathrm{~N}_{\mathrm{CD} 1}=18, \mathrm{~N}_{\mathrm{CD} 2}=13$ ), which was used to test whether the sub-clusters differed significantly. The sub-clusters underlined by the same line were not significantly different in post-hoc comparisons. 


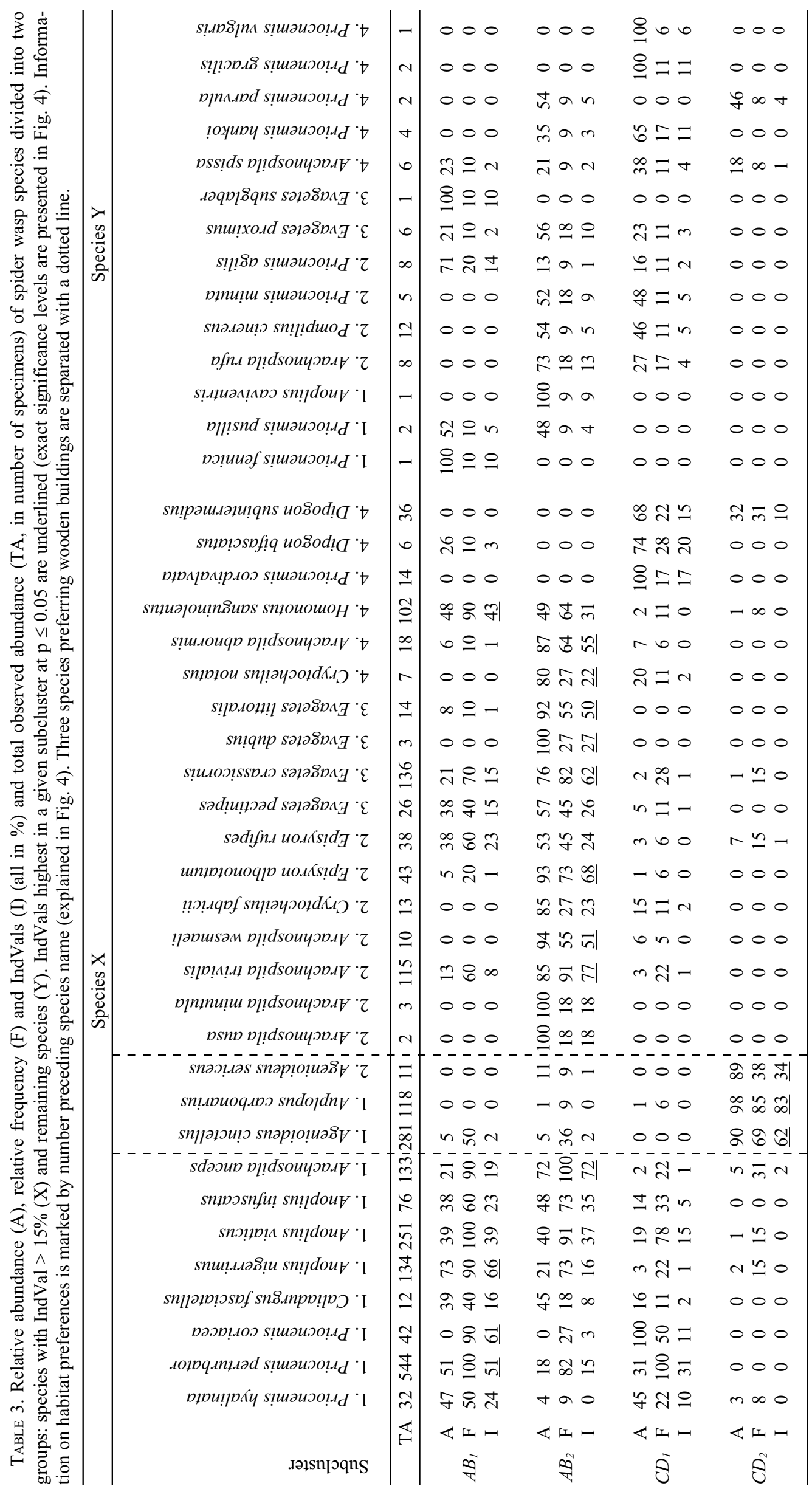




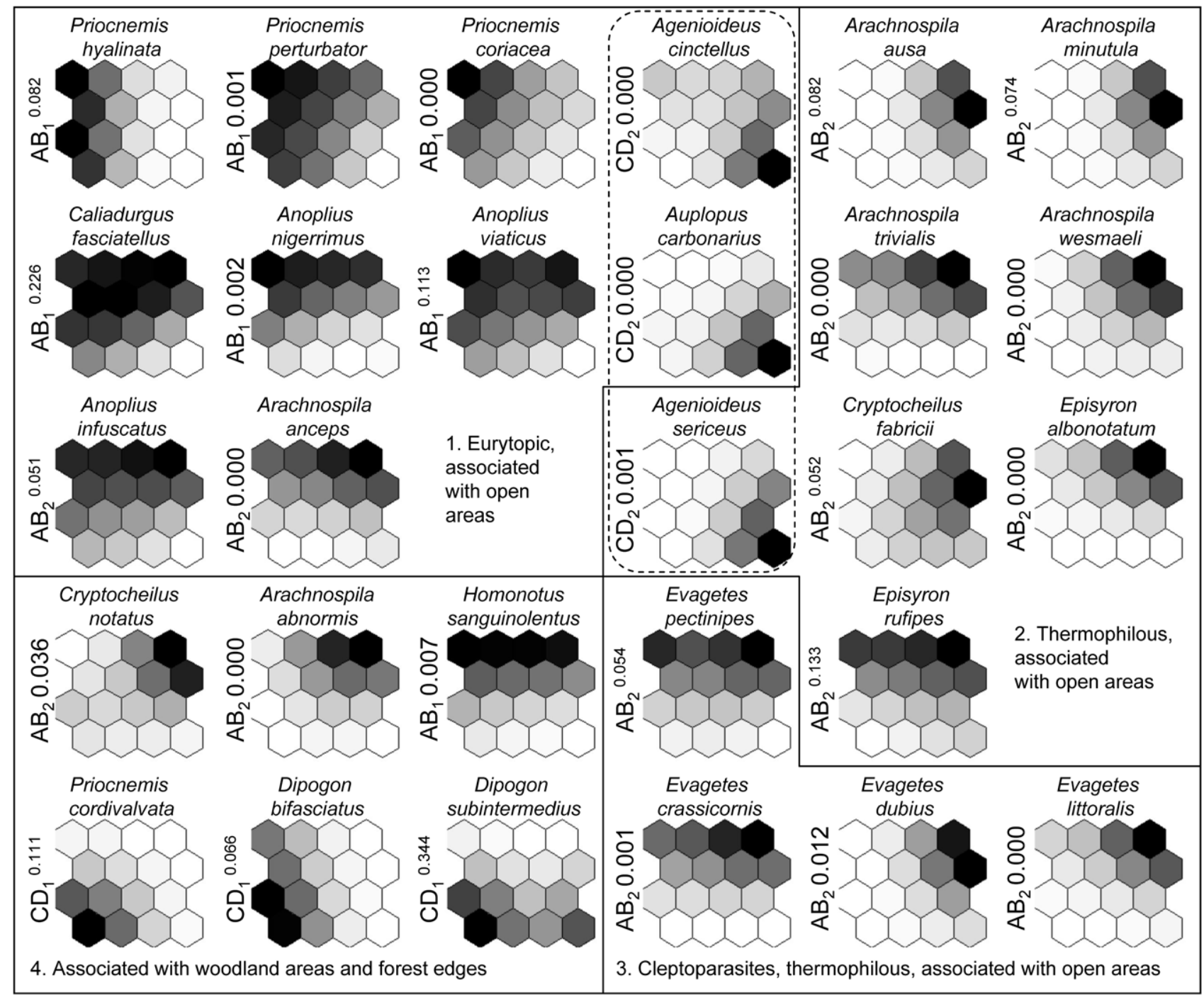

Fig. 4. Importance, greater the darker the shading, of the 28 species of spider wasp with IndVals $>15 \%$ (compare with Table 3 ) in the models of the spider wasp samples. The shading is scaled independently for each species. The three species associated with wooden buildings are enclosed by a dotted line. The symbol of the sub-cluster with the maximum indicator value (IndVal) recorded for a given species, and the respective significance level (in superscript if $>0.05$ ) are presented on the left side of each species plane. Species with the same pattern in the SOM occurred in similar habitats.

was recorded for samples in $\mathrm{AB}_{2}\left(33\right.$ species) than $\mathrm{AB}_{1}$ and $\mathrm{CD}_{1}$ (in each 24 species) and the fewest species (8) were recorded in $\mathrm{CD}_{2}$ (Table 3).

According to the patterns in the species importance in the SOM and to the IndVals each cluster/sub-cluster can be characterized by species strongly associated with it and thus with relevant types of habitats (Fig. 4 and Table $3)$. In sub-cluster $A B_{1}$, the significant highest IndVals were recorded for 3 eurytopic species (group 1): Priocnemis perturbator, P. coriacea Dahlbom, 1843, Anoplius nigerrimus (Scopoli, 1763), and a species preferring woodland areas and forest margins (group 4): Homonotus sanguinolentus (Fabricius, 1793) (Fig. 4 and Table 3). Sub-cluster $\mathrm{AB}_{2}$ was characterized by thermophilous species (group 2): Arachnospila trivialis (Dahlbom, 1843), A. wesmaeli (Thomson, 1870), Episyron albonotatum (Vander Linden, 1827), their obligate brood parasites (group 3): Evagetes crassicornis (Schuckard, 1837), E. dubius (Vander Linden, 1827) and E. littoralis (Wesmael,
1851), an eurytopic species (group 1): Arachnospila anceps (Wesmael, 1851) and species preferring woodlands and forest edges (group 4): Cryptocheilus notatus (Rossius, 1792) and Arachnospila abnormis (Dahlbom, 1842). Thus, in general mainly eurytopic and thermophilous species (groups 1-3) were associated with cluster $\mathrm{AB}$. In sub-cluster $\mathrm{CD}_{1}$ none of the species had a significant maximum IndVal. Nevertheless, Priocnemis cordivalvata Haupt, 1927, P. gracilis and P. vulgaris (all associated with woodlands and forests edges, group 4) were recorded only in samples assigned to this sub-cluster (Table 3). Sub-cluster $\mathrm{CD}_{2}$ (with respective environmental conditions) was preferred by three species, the eurytopic Agenioideus cinctellus (Spinola, 1808) and Auplopus carbonarius (Scopoli, 1763) (group 1) and thermophilous Agenioideus sericeus Vander Linden, 1827) (group 2), all three recorded mainly on wooden buildings. Generally cluster CD (and relevant habitats) was attractive for eurytopic species and those preferring woodland areas and 
TABLE 4. Species of spider wasps with IndVal $>15 \%$ (compare to Table 3) classified according to the nesting behaviour: (i) no nest constructing - leaving prey in situ, (ii) no nest constructing - cleptoparasites, (iii) digging nest in the ground, (iv) nesting in pre-existing cavities in ground, (v) nesting in preexisting cavities in or above the ground, (vi) nesting in preexisting cavities above the ground, (vii) constructing free standing nest above ground. The subcluster with the maximum observed IndVal for each species is given (and underlined if $\mathrm{p}<$ $0.05)$.

\begin{tabular}{|c|c|c|}
\hline Group & Species & Subcluster \\
\hline $\mathrm{i}$ & Homonotus sanguinolentus & $\underline{\mathrm{AB}_{1}}$ \\
\hline \multirow[t]{4}{*}{ ii } & Evagetes pectinipes & $\mathrm{AB}_{2}$ \\
\hline & Evagetes crassicornis & $\underline{\mathrm{AB}_{2}}$ \\
\hline & Evagetes dubius & $\underline{\mathrm{AB}_{2}}$ \\
\hline & Evagetes littoralis & $\underline{\mathrm{AB}_{2}}$ \\
\hline \multirow[t]{10}{*}{ iii } & Caliadurgus fasciatellus & $\mathrm{AB}_{1}$ \\
\hline & Anoplius viaticus & $\mathrm{AB}_{1}$ \\
\hline & Anoplius infuscatus & $\mathrm{AB}_{2}$ \\
\hline & Episyron albonotatum & $\underline{\mathrm{AB}_{2}}$ \\
\hline & Episyron rufipes & $\overline{\mathrm{AB}_{2}}$ \\
\hline & Arachnospila anceps & $\underline{\mathrm{AB}_{2}}$ \\
\hline & Arachnospila ausa & $\mathrm{AB}_{2}$ \\
\hline & Arachnospila trivialis & $\underline{\mathrm{AB}_{2}}$ \\
\hline & Arachnospila wesmaeli & $\underline{\mathrm{AB}_{2}}$ \\
\hline & Cryptocheilus notatus & $\underline{\mathrm{AB}_{2}}$ \\
\hline \multirow[t]{5}{*}{ iv } & Priocnemis coriacea & $\mathrm{AB}_{1}$ \\
\hline & Priocnemis perturbator & $\underline{\mathrm{AB}_{1}}$ \\
\hline & Arachnospila minutula & $\mathrm{AB}_{2}$ \\
\hline & Arachnospila abnormis & $\underline{\mathrm{AB}_{2}}$ \\
\hline & Cryptocheilus fabricii & $\overrightarrow{\mathrm{AB}_{2}}$ \\
\hline \multirow[t]{5}{*}{$\mathrm{v}$} & Anoplius nigerrimus & $\underline{\mathrm{AB}_{1}}$ \\
\hline & Priocnemis hyalinata & $\mathrm{AB}_{1}$ \\
\hline & Priocnemis cordivalvata & $\mathrm{CD}_{1}$ \\
\hline & Dipogon subintermedius & $\mathrm{CD}_{1}$ \\
\hline & Agenioideus sericeus & $\underline{\mathrm{CD}_{2}}$ \\
\hline \multirow[t]{2}{*}{ vi } & Dipogon bifasciatus & $\mathrm{CD}_{1}$ \\
\hline & Agenioideus cinctellus & $\underline{\mathrm{CD}_{2}}$ \\
\hline vii & Auplopus carbonarius & $\underline{\mathrm{CD}_{2}}$ \\
\hline
\end{tabular}

forest edges (groups 1 and 4) (Table 3). It should be noted that if a species is not significantly associated with any particular region of the SOM this is because it either has a wide environmental tolerance or low abundance and frequency in samples, which results in the differences between sub-clusters being insignificant.

Species within most ecological groups of spider wasps had very similar patterns on the SOM, i.e., very similar habitat preferences. In groups 1 and 2, species recorded mainly on wooden buildings with significant maximum IndVals were placed in an additional sub-group (Fig. 4 and Table 3). The remaining eurytopic species (group 1) were associated mainly with cluster $A B$, though they were also present in sub-cluster $\mathrm{CD}_{1}$ (Table 3). Other thermophilous species (group 2) and their cleptoparasites (group 3) were clearly associated with sub-cluster $\mathrm{AB}_{2}$. Moreover, 3 species: Arachnospila ausa (Tournier, 1890), A. minutula (Dahlbom, 1842) and Evagetes dubius, were recorded only in samples assigned to this sub-cluster. Group 4, which includes species preferring woodlands and forest edges, was the least homogenous in terms of SOM patterns. Three species were associated mainly with cluster $\mathrm{AB}$ and three others with cluster $\mathrm{CD}$ (Fig. 4 and Table 3).

As far as the nesting preferences are concerned (Table 4), one species, Homonotus sanquinolentus (Fabricius, 1793), which does not construct a nest and is assigned to a separate guild (guild i), had a significant highest IndVal in sub-cluster $A_{1}$. Among the other guilds, guild $v$, which includes species nesting in pre-existing cavities in the ground or above it, was the most heterogeneous, as its species attained the maximum observed relative abundances and/or frequencies in the different sub-clusters, except $\mathrm{AB}_{2}$ (Table 3 and 4). The remaining guilds were associated with only one cluster. The endogeic species (guilds iii and iv) without exception were significantly associated with cluster AB (Table 4). Among them the endogeic species nesting in pre-existing cavities in the ground (guild iv) were most common both in sub-clusters $\mathrm{AB}_{1}$ and $\mathrm{AB}_{2}$, while species excavating nests in the ground (guild iii) in sub-cluster $\mathrm{AB}_{2}$ (except for Caliadurgus fasciatellus (Spinola, 1808) and Anoplius viaticus). Similarly, cleptoparasites (guild ii) of species in guild iii were associated mostly with sub-cluster $\mathrm{AB}_{2}$. Species in guilds vi and vii, which nest in pre-existing cavities above ground and construct free standing nests above ground, were most common in cluster CD (Table 4). In summary, endogeic species, excavating nests in the ground, and their cleptoparasites, were mainly associated with sub-cluster $\mathrm{AB}_{2}$ and hypergeic and endogeic/hypergeic species with sub-clusters $\mathrm{CD}_{1}$ and $\mathrm{CD}_{2}$.

\section{DISCUSSION}

The number of species caught during this study is approximately half the number of spider wasps recorded in Poland (Wiśniowski, 2009). This proportion is similar to that recorded for other Aculeata taxa in the Kampinoski National Park (Szczepko \& Kowalczyk, 2001; Szczepko et al., 2002, 2009; Szczepko \& Wiśniowski, 2009). Moreover, the species richness of spider wasps in the KNP (42 species) is distinctly higher than recorded in other studies carried out in the south of Poland: 28 species in the Ojców National Park and 21 in the Magurski National Park (Wiśniowski, 2005; Wiśniowski \& Werstak, 2009, respectively).

The KNP, together with its buffer zone, is one of the most important faunal refugia in the Polish lowlands. The area offers a wide spectrum of environments for fauna associated with open areas of various types and origins as well as different forests (Andrzejewski, 2003). Although the number of samples assigned to cluster $A B$ was low, the number of species and their abundance and frequency recorded in these samples (collected in open areas often located on dry soil) were higher than those recorded for samples in cluster CD (i.e., samples from forests, buildings and pioneer fallows on humid soil). The majority of pompilid species are inhabitants of relatively open locations and few inhabit woodlands or forests (Day, 1988; 
Wiśniowski, 2009). Moreover, the occurrence of species and the richness and composition of assemblages depend not only on the character of a site but also its position in the land mosaic (Bennet et al., 2006). The diversity of the surrounding landscape influenced the spatial distribution patterns of spider wasp species in the KNP. In cluster AB, which includes samples from open sites surrounded by more diverse landscapes, the number and abundance of species in samples were higher than in cluster $\mathrm{CD}$, which includes samples from more homogenous areas (Fig. 3). More diverse surroundings could increase the amount of available resources or provide additional, new resources (Dunning et al., 1992) like nectar, hosts, nesting sites or over-wintering sites (Weibull et al., 2000; SteffanDewenter, 2002; Steffan-Dewenter et al., 2002; Tscharntke et al., 2002, 2005). Spider wasp species could use different habitats within their flight range (Taylor et al., 1993; Klein et al., 2004) to fulfil their specific requirements (Wiśniowski, 2009). A good example is a sample from an open fragment of sand dune assigned to the same neuron (D1) as samples from forests (Fig. 2). At first sight this appears anomalous. Nevertheless, this open fragment of sand dune is small and surrounded on all sides by mixed forest. This explains why species typical of forests, flying over the dune, were caught by the traps located there. Our results are congruent with those of other studies in which more diverse habitats favour more diverse insect communities (Duelli, 1997; Weibull et al., 2000; Steffan-Dewenter, 2002; Tscharntke et al., 2002), by offering a variety of feeding resources, nesting sites and refugia for taxa with different living requirements (Evans \& Yoshimoto, 1962).

The different associations of pompilid species with different habitats might also be explained by differences in their nesting biology. According to Evans \& Yoshimoto (1962) and Kurczewski et al. (1988) habitat (soil type and cover of vegetation) is a good indicator of the distribution of pompilid taxa. Nesting resources are important for particular species of spider wasp as well as shape their assemblages (Evans \& Yoshimoto, 1962; Kurczewski et al., 1988; Wiśniowski, 2009). In our study, the presence of species nesting obligatorily in the ground (endogeic, ground-nesters), particularly those that dig nests, is generally limited to sites with exposed areas of friable soil, while those nesting above ground are able to nest in a variety of places, of which some are unavailable to ground-nesters (Evans \& West-Eberhard, 1970; Potts et al., 2005). Because most species of spider wasp are associated with open areas and are thermophilous ground nesters (Day, 1988; Wiśniowski, 2009) the number of species with significant maximum IndVals (9) was greatest in sub-cluster $\mathrm{AB}_{2}$, which includes samples from old fallows on dry, sandy soils located in a diverse landscape. In contrast, in the sub-cluster $\mathrm{CD}_{1}$ that contained all the samples from forests and almost all samples from fallows on hydrogenic soils, and had the lowest median of mosaicity measure, there were no species with significant IndVals, which indicates that the number of such species may serve as a bio-indicator of environmental quality for a given group of animals. Furthermore, the number of species with significant IndVals varies to some extent independently of species richness as both variables were highest in $\mathrm{AB}_{2}$, but the number of species with significant IndVals was not lowest in the sub-cluster with the lowest species richness $\left(\mathrm{CD}_{2}\right)$.

Generally, the SOM identified species associated with similar or completely different habitats (i.e., with the same or an opposite pattern on the SOM, respectively). Some of them only occur in particular habitats (stenotopic), while others are common and occur in a wide range of different habitats (eurytopic) (Wiśniowski, 2009). Eurytopic species with very different nesting requirements are mainly associated with fallows and meadows $\left(\mathrm{AB}_{1}\right)$. Thermophilous and endogeic species, especially those that dig nests and their cleptoparasites are mainly associated with fallow abandoned a long time ago on dry, sandy soils $\left(\mathrm{AB}_{2}\right)$. The species significantly associated with this kind of habitats are Arachnospila trivialis, A. wesmaeli and Episyron albonotatum, which occur at warm sites where they excavate nests in loose sand (Day, 1988; Wiśniowski, 2009), and their obligate brood parasites: Evagetes crassicornis, E. dubius E. littoralis and E. pectinipes (Linnaeus, 1758). Moreover, sub-cluster $\mathrm{AB}_{2}$ includes all the samples with the following three species: (1) the thermophilous and endogeic Arachnospila ausa and $A$. minutula, which are strictly associated and nest in areas with sparse vegetation on sandy ground (Wiśniowski, 2009), and (2) Evagetes dubius, which is a cleptoparasite of $A$. minutula (Day, 1988; Wiśniowski, 2009). Species insignificantly associated with forests and fallows on hydrogenic soils $\left(\mathrm{CD}_{1}\right)$, i.e. Priocnemis cordivalvata, Dipogon subintermedius (Magretti, 1886) and D. bifasciatus (Geoffroy, 1785), belong to hypergeic guilds. This observation is consistent with the results of other studies carried out in Poland, in which they are recorded mainly occurring in sunny edges of forests, where they nest in the burrows of wood borers in dead wood or empty hollow stems (Wiśniowski, 2009). In the light of the latter information it is worth noting that of these three species only $D$. subintermedius was recorded on wooden buildings $\left(\mathrm{CD}_{2}\right)$. The latter habitat was markedly preferred by three species (Agenioideus cinctellus, A. sericeus and Auplopus carbonarius) with different ecological amplitude, both eurytopic and thermophilous. They belong to three nesting guilds (v, vi and vii) and are species that nest obligatorily or facultatively above the ground. They may be examples of "cultural species" (Duelli \& Obrist, 2003a), which are mainly associated with anthropogenic habitats ("cultural" habitats) (Bennet et al., 2006) but sometimes occur (also in the KNP) in non-anthropogenic habitats (Duelli \& Obrist 2003b; Tscharntke et al., 2005). Since adult pompilids feed on nectar (Wiśniowski, 2009) the presence of garden flowers and honeydew might be an important factor for them. Furthermore, these species hunt for spiders on the walls of buildings and may use cavities in the walls for nesting, which is suggested for the genus Agenioideus (Kurczewski \& Spofford, 1986; Wiśniowski, 2009) and A. carbonarius (Day, 1988). 
Their spectrum of prey is wide and includes both active and web building spiders. In contrast, $P$. cordivalvata, $D$. subintermedius and D. bifasciatus only hunt for active spiders, which may be why they were absent or much rarer on wooden buildings though they nest in dead wood (Uetz et al., 1999; Wiśniowski, 2009).

In summary, this study highlights not only the importance of open habitats like old fallows and meadows, already known to be good habitats for spider wasps (Day, 1988; Wiśniowski, 2009), but also the importance of anthropogenic sites. Our results support the hypothesis that both pompilid species richness and abundance are positively associated with landscape mosaicity, and are consistent with the concept that habitat heterogeneity enhances faunal diversity as each type of habitat (including anthropogenic ones) widens the range of available resources (Benett et al., 2006).

ACKNOWLEDGEMENTS. The authors would like to thank B. Wiśniowski at the Ojców National Park for his help in the identification of spider wasps and valuable comments on their biology, D. Michalska-Hejduk for help with the botanical determination of the habitats, D. Kopeć for making available a GIS map of soils of the KNP and D. Pietraszewski for help with the drawing of the map of the study area. The authors are especially grateful to Ł. Głowacki (University of Łódź, Poland), B.J. Armitage (USA) and A.F.G. Dixon (University of Norwich, UK) for correcting the English.

\section{REFERENCES}

Andrzejewski R. 2003: Kampinos National Park. Kampinoski Park Narodowy, Izabelin, 728 pp. [in Polish].

Bańbura M., Sulikowska-Drozd A., Kaliński A., Skwarska J., WaWrzyniak J., KRUK A., ZielińsKi P. \& BańbURA J. 2010: Egg size variation in Blue Tits Cyanistes caeruleus and Great Tits Parus major in relation to habitat differences in snail abundance. Acta Ornithol. 45: 121-129.

Bennett A.F., Radford J.Q. \& Haslem A. 2006: Properties of land mosaics: Implications for nature conservation in agricultural environments. Biol. Conserv. 133: 250-264.

BuschinI M.L.T. \& WoIsKi T.D. 2008: Alpha-beta diversity in trap-nesting wasps (Hymenoptera: Aculeata) in Southern Brazil. Acta Zool. 89: 351-358.

Céréghino R., Ruggiero A., Marty P. \& Angélibert S. 2008 Biodiversity and distribution patterns of freshwater invertebrates in farm ponds of a south-western French agricultural landscape. Hydrobiologia 597: 43-51.

ChOn T.S., KwAK I.S., PARK Y.S., KIM T.H. \& KIM Y. 2001: Patterning and short-term predictions of benthic macroinvertebrate community dynamics by using a recurrent artificial neutral network. Ecol. Modell. 146: 181-193.

Corbara B., Carpenter J.M., Céréghino R., Leponce M., Gibernau M. \& Dejean A. 2009: Diversity and nest site selection of social wasps along Guianese forest edges: assessing the influence of arboreal ants. C. R. Biologies 332: 470-479.

DAY M.C. 1988: Spider Wasps. Hymenoptera: Pompilidae. Handbook for the Identification of British Insects. Royal Entomological Society of London, Dorset, $60 \mathrm{pp}$.

Delabie J.H.C., Céréghino R., Groc S., Dejean A., Gibernau M., Corbara B. \& Dejean A. 2009: Ants as biological indicators of Wayana Amerindian land use in French Guiana. C. $R$. Biologies 332: 673-684.
Duelli P. 1997: Biodiversity evaluation in agricultural landscapes. An approach at two different scales. Agric. Ecosyst. Environ. 62: 81-91.

Duelli P. \& OBrist M.K. 2003a: Population movements of arthropods between natural and cultivated areas. Biol. Conserv. 54: 193-208.

Duelli P. \& OBRist M.K. 2003b: Regional biodiversity in an agricultural landscape: the contribition of seminatural habitat islands. Basic Appl. Ecol. 4: 129-138.

Duelli P., Obrist M.K. \& Schmatz D.R. 1998: Biodiversity evaluation in agricultural landscapes: above-ground insects. Agric. Ecosyst. Environ. 74: 33-64.

Dufrêne M. \& Legendre P. 1997: Species assemblages and indicator species: the need for flexible asymmetrical approach. Ecol. Monograph. 67: 345-366.

Dunning J.B., Danielson B.J. \& Pulliam R. 1992: Ecological processes that affect populations in complex landscapes. Oikos 65: 169-175.

Evans E.H. \& Yoshimoto C.M. 1962: The ecology and nesting behaviour of the Pompilidae (Hymenoptera) of the Northern United States. Misc. Publ. Entomol. Soc. Am. 3: 65-119.

Evans H.E. \& West-Eberhard M.J. 1970: The Wasps. The University of Michigan Press, Ann Arbor, 265 pp.

Fauna Europaea 2010: Fauna Europaea, version 2.3. Available online at http://www.faunaeur.org (accessed 23 December, 2010).

FincH O.-D. 1997: Spider wasps (Hymenoptera, Pompilidae) as predators of spider taxocenosis. In Żabka M. (ed.): Proc. $16^{\text {th }}$ Europ. Coll. Arachnol. Wyższa Szkola Rolniczo-Pedagogiczna, Siedlce, pp. 83-89.

Groc S., Delabie J.H.C., Céréghino R., Orivel J., Jaladeau F., Grangier J., Mariano C.S.F. \& Dejean A. 2007: Ant species diversity in the "Grands Causses" (Aveyron, France): In search of sampling methods adapted to temperate climates. $C$. R. Biologies 330: 913-922.

Klein A.-M., Steffan-Dewenter I. \& Tscharntke T. 2004: Foraging trip duration and density of megachilid bees, eumenid wasps and pompilid wasps in tropical agroforestry systems. $J$. Anim. Ecol. 73: 517-525.

Konecka-Betley K. 2003: The soils of Kampinos National Park. In Andrzejewski R. (ed.): Kampinos National Park. Part I. Kampinoski Park Narodowy, Izabelin, pp. 97-133 [in Polish].

KuRczewsKi F.E. \& Spofford M.G. 1986: Observation on the behaviours of some Scoliidae and Pompilidae (Hymenoptera) in Florida. Fla. Entomol. 69: 636-644.

Kurczewski F.E., Kurczewski E.J. \& Spofford M.G. 1988: Nesting behaviour of Aporinellus wheeleri Bequaert and A. taeniolatus (Dalla Torre) (Hymenoptera: Pompilidae). Proc. Entomol. Soc. Wash. 90: 294-306.

Lek S., Scardi M., Verdonschot P.F.M., Descy J.P. \& Park Y.S. 2005: Modelling Community Structure in Freshwater Ecosystems. Springer, Berlin, 518 pp.

Lek-Ang S., Park Y.-S., Ait-Mouloud S. \& Deharveng L. 2007: Collembolan communities in a pet bog versus surrounding forest analyzed by using self-organizing map. Ecol. Modell. 203: 9-17.

O’Neill K.M. 2001: Solitary Wasps. Behaviour and Natural History. Cornell University Press, Ithaca, London, 406 pp.

Oenlke J. \& Wolf H. 1987: Beiträge zur Insekten-Fauna der DDR: Hymenoptera - Pompilidae. Beitr. Entomol. 37: 279-390.

PARK Y.-S. \& Chung Y.-J. 2006: Hazard rating of pine trees from a forest insect pest using artificial neural networks. Forest Ecol. Manag. 222: 222-233. 
Park Y.-S., Céréghino R., Compin A. \& Lek S. 2003: Application of artificial neural networks for patterning and predicting aquatic insect species richness in running waters. Ecol. Modell. 160: 265-280.

Penczak T., Kruk A., Grzybkowska M. \& Dukowska M. 2006 Patterning of impoundment impact on chironomid assemblages and their environment with the use of the selforganizing map (SOM). Acta Oecol. 30: 312-321.

Potts S.G., Vulliamy B., Robersts S., O'Toole C., Dafni A., Ne'EMAn G. \& Willmer P. 2005: Role of nesting resources in organizing diverse bee communities in Mediterranean landscape. Ecol. Entomol. 30: 78-85.

Quinn G.P. \& Keough M.J. 2002: Experimental Design and Data Analysis for Biologists. Cambridge University Press, Cambridge, $537 \mathrm{pp}$.

Ruggiero A., Céréghino R., Figuerola J., Marty P. \& AngéLIBERT S. 2008: Farm ponds make a contribution to the biodiversity of aquatic insects in a French agricultural landscape. C. R. Biologies 331: 298-308.

SChMid-EgGer C. \& SMISSEN J. vAN DER 1995: Ergänzende Bestimmungsmerkmale für verschiedene Arten der Gattung Priocnemis (Hymenoptera: Pompilidae). Bembix 4: 37-44.

Shlyakhtenok A.S. 2007: Hymenoptera: Aculeata of raised bogs in Belarus. Entomol. Rev. 87: 136-147.

Shlyakhtenok A.S. \& Agunovich R.G. 2001: The dynamics of species composition and abundance of wasps from families Pompilidae, Sphecidae, and Vespidae (Hymenoptera: Aculeata) in successional pine biogeocenoses of the Berezinskii Biosphere Reserve. Russ. J. Ecol. 32: 126-129.

SKIBIŃSKA E. 1989a: Aculeata (Hymenoptera) of linden-oakhornbeam and thermphilous oak forests of the Mazovian Lowlan. Fragm. Faun. 32: 197-223.

SKIBIŃSKA E. 1989b: Predatory Aculeata (Hymenoptera) of moist meadows on the Mazovian Lowland. Memorab. Zool. 43: 289-296.

SMissen J. VAN DeR 1994: Zur Kenntnis der Weibchen von Arachnospila virgilabnormis Wolf, 1976 und Arachnospila alvarabnormis (Wolf, 1965) (Hymenoptera: Pompilidae). Drosera 1/2: 63-70.

SMISSEN J. van DER 1996a: Zur Unterscheidung der PompilidenWeibchen Arachnospila fumipennis (Zetterstedt) und A. consobrina (Dahlbom). Bembix 7: 21-24.

SMISSEN J. vAN DER 1996b: Zur Kenntnis einzelner ArachnospilaWeibchen - mit Bestimmungsschlüssel für die geringbehaarten, kammdorntragenden Weibchen der Gattung Arachnospila Kincaid, 1900 (Hymenoptera: Pompilidae). Drosera 1996: 73-102.

SMISSEN J. VAN DER 1998: Die Weibchen von Priocnemis parvula Dahlbom 1845 und P. minutalis Wahis 1979. Bembix 10: $37-41$.

SMISSEN J. VAN DER 2003: Revision der europäischen und türkischen Arten der Gattung Evagetes Lepeletier 1845 unter Berücksichtigung der Geäderabweichungen. Mit zweisprachigem Schlüssel zur determination (Hymenoptera: Pompilidae). Verh. Ver. Naturw. Heimatforsch. Hamburg 42: 1-253.

Song M.-Y., Park Y.-S., KwaK I.-S., Woo H. \& ChON T.-S. 2006: Characterization of benthic macroinvertebrate communities in a restored stream by using self-organizing map. Ecol. Inform. 1: 295-305.

Speight M.R., Hunter M.D. \& Watt A.D. 2008: Ecology of Insects: Concepts and Applications. 2nd ed. Wiley-Blackwell, Chichester, $628 \mathrm{pp}$.
StefFan-Dewenter I. 2002: Landscape context affects trapnesting bees, wasps, and their natural enemies. Ecol. Entomol. 27: 631-637.

Steffan-Dewenter I., Münzenberg U., Bürger C., Thies C. \& TSCHARNTKE T. 2002: Scale-dependent effects of landscape context on three pollinator guilds. Ecology 83: 1421-1432.

SzCZEPKo K. \& KowAlCZYK J.K. 2001: Sphecid wasps (Hymenoptera: Sphecidae) in habitats of abandoned village in forest territory of Kampinos National Park (Poland). Pol. J. Entomol. 70: 185-193.

SzczepKo K. \& WiśnIOWsKi B. 2009: Aculeata (Hymenoptera) of the Kampinos National Park. Part III. Ruby-tailed wasps (Chrysididae). Wiad. Entomol. 28: 163-182 [in Polish].

Szczepko K., Pawlikowski T. \& KowalczyK J.K. 2002: Apoidea (Hymenoptera) in habitats of former agriculture area in a renaturization stage of Kampinos National Park (Poland). Fragm. Faun. 45: 115-122.

SzcZePKo K., WiśnIOWSKI B. \& ŻyŁA W. 2009: Aculeata (Hymenoptera) of Kampinos National Park. Part V. Wasps (Vespidae). Wiad. Entomol. 28: 235-258 [in Polish].

Taylor P.D., Fahrig L., Henein K. \& Merriam G. 1993: Connectivity is a vital element of landscape structure. Oikos $\mathbf{6 8}$ : 571-576.

Tscharntke T., Gathmann A. \& Steffan-Dewenter I. 1998: Bioindication using trap-nesting bees and wasps and their natural enemies: community structure and interactions. $J$. Appl. Ecol. 35: 708-719.

Tscharntke T., Steffan-Dewenter I., Kruess A. \& Thies C. 2002: Contribution of small habitat fragments to conservation of insect communities of grassland-cropland landscapes. Ecol. Appl. 12: 354-363.

Tscharntke T., Rand T.A. \& Bianchi F.J.J.A. 2005: The landscape context of trophic interactions: insect spillover across the crop-noncrop interface. Ann. Zool. Fenn. 42: 421-432.

TsZYdel M., GrzyBKowsKa M. \& KRUK A. 2009: Influence of dam removal on trichopteran assemblages in the lowland Drzewiczka River, Poland. Hydrobiologia 630: 75-89.

Uetz G.W., HalaJ J. \& CADY A.B. 1999: Guild structure of spiders in major crops. J. Arachnol. 27: 270-280.

Weibull A.-C., Bengstonn J. \& Nohlgren E. 2000: Diversity of butterflies in the agricultural landscape: the role of farming system and landscape heterogeneity. Ecography 23: 743-750.

Westphal C., Bommarco R., Carré G., Lamborm E., Morison N., Petanidou T., Potts S.G., Roberts S.P.M., Szentgyörgyi H., Tscheulin T., Vaissičre B.E., Woyciechowski M., Biesmeijer J.C., Kunin W.E., Settele J. \& Steffan-Dewenter I. 2008: Measuring bee diversity in different European habitats and biogeographical regions. Ecol. Monograph. 78: 653-671.

Wiśniowski B. 2005: Tiphiidae, Sapygidae, Mutillidae, Pompilidae, Eumenidae, Vespidae and Sphecidae (Hymenoptera: Aculeata) of Ojców National Park. Part 2. Analysis of aculeate assemblages. Prqdnik. Prace Muz. Szafera 15: 31-338 [in Polish].

WIŚNIOwski B. 2009: Spider-Hunting Wasps (Hymenoptera: Pompilidae) of Poland. Diversity, Identification, Distribution. Ojców National Park, Ojców, 432 pp.

WiśnIOWSKI B. \& WerstaK K. 2009: Contribution to the knowledge of spider-hunting wasps and social wasps (Hymenoptera: Aculeata: Pompilidae, Vespidae) of Magurski National Park, SE Poland. Rocz. Bieszcz. 17: 339-355 [in Polish].

ZAR J.H. 1984: Biostatistical Analysis. Englewood Cliffs, Prentice-Hall, NJ, 718 pp.

Received April 18, 2011; revised and accepted August 12, 2011 